\title{
SECTORAL COMPOSITION AND TAX REVENUE PERFORMANCE IN ECOWAS COUNTRIES
}

\author{
Nosakhare Liberty Arodoye*, John Norense Izevbigie \\ Department of Economics, University of Benin, Nigeria \\ nosakhare.arodoye@uniben.edu \\ norense.izevbigie@uniben.edu
}

\begin{abstract}
The study investigates sectoral composition and tax revenue performance in ECOWAS countries. Specifically, the study examines taxable capacity, tax efforts and tax structure of thirteen Economic Community of West African States (ECOWAS) countries taking into account three major sectors comprising agriculture, service and industrial sectors for the period 2000 to 2015. This is meant to bridge the gap in the extant literature which mainly focused on tax revenue to gross domestic product without taking into account taxable capacity and tax efforts with respect to specific sectors of the economy. The study employed stochastic frontier, forecast error variance decomposition, vector autoregression and the generalized methods of moment accordingly in the empirical analysis. The result from the analysis shows that the hypothesis of a low taxable capacity and tax efforts in the agricultural, industrial and service sectors in ECOWAS countries should be rejected. Specifically, the result revealed that though the three sectors are yet to be maximally exploited, the taxable capacity of ECOWAS countries is reasonably high. Also, the service and industrial sectors express more favourable responses to the tax revenue performance compared to the agricultural sector. It was recommended among others that on the average the governments of ECOWAS countries should formalize and strengthens tax revenue collections in the agricultural, service and industrial sectors.
\end{abstract}

Keywords: Stochastic Frontier; ECOWAS; Taxation; Revenue.

JEL: C53, F02, H20, H27.

\section{Introduction}

The assessment of the taxable capacity, tax efforts and tax structure of Economic Community of West Africa States (ECOWAS) countries taking into account sectoral composition of countries in the sub-region is imperative for a better understanding of the overall tax revenue performance of the countries in the sub-region. These will no doubt help to ease and strengthen the level of international comparability of the countries' tax efforts. This study specifically examines the taxable capacity, tax effort and tax structure in three major sectors vis-a-vis agriculture, industry and services in relation to total tax, direct tax and indirect tax as well as inter-country comparisons of the average tax potential and tax effort estimates in thirteen ECOWAS countries for the period spanning 2000 to 2015 . This is at variant with most studies in the extant literature that mainly focused on tax revenue to gross domestic product without taking a look at taxable capacity and tax efforts with respect to specific sectors of the economy. The working hypothesis is that there are low taxable capacity and tax efforts in the agricultural, industrial and service sectors in ECOWAS countries.

\footnotetext{
* Corresponding author: Nosakhare Liberty Arodoye
} 
Following this introductory remark is theoretical issues and theoretical framework. This was also followed by model specification and estimation techniques, empirical analysis, implications of the findings, recommendations and conclusion.

\section{Theoretical Issues and Theoretical Framework}

The foremost authors who examined the existence of the relationship between "the level of development" and "the structure of taxation" were Hinrichs (1966) and Musgrave (1969) and in terms of the examination of international cross-section comparisons, both researchers' strongly believed that the dearth of simple mechanisms of collecting tax revenues characterized the early stages of development. Musgrave and Musgrave (1982) note that the progress in the scope and nature of economic activities stimulates sales and production so as to broaden the scope of indirect taxation as a more stable tool for additional mobilization of tax revenue.

Taking into account our interest in taxable capacity and/or tax performance of the ECOWAS countries, we took actual tax shares as a function of desired tax share and tax bases that lend themselves to taxation. Hence, we incorporated specific sectoral compositions as elements of tax bases. This understanding will give us the following functional relationship:

$$
\left(\frac{T}{Y}\right)_{i, t}=f\left[\left(\frac{T}{Y}\right)_{i, t}^{*} B_{i, t}\right]
$$

Where: $\left(\frac{T}{Y}\right)_{i, t}=$ Total tax, direct tax and indirect tax shares; $\left(\frac{T}{Y}\right)_{i, t}^{*}=$ desired tax shares at time "t" in selected ECOWAS countries "i" and $B_{i, t}=$ vector of tax bases at time "t" in selected ECOWAS countries "i”.

In finding the various element of tax bases, this study have demonstrated that specific tax bases significantly influence tax shares (total taxes, direct taxes and indirect taxes). Therefore, the effects of some tax bases (for example, agriculture as a share of GDP, industry value added and service value added) are endogenously incorporated in developing the general framework for this study. Hence, the functional expression for the tax bases is presented in a panel data framework as:

$$
B_{i, t}=f\left[A y_{i, t}, S e r_{-} g d p_{i, t}, \text { ind } \_g d p_{i, t}\right]
$$

Where:

$A y_{i, t} \quad=$ the share of agriculture (A) in income(y) at time " $\mathrm{t}$ " in selected ECOWAS countries ser_ $g d p_{i, t}=$ Service value added ind $\_g d p_{i, t}=$ industry value added

$$
\left(\frac{T}{Y}\right)_{i, t}=f\left[\left(\frac{T}{Y}\right)_{i, t}^{*}, A y_{i, t}, s e r_{-} g d p_{i, t}, i n d_{-} g d p_{i, t}\right]
$$

The above hypothesized relationship (without the desired tax shares which will be examined with the stochastic frontier model) yielded the following fundamental model for this study:

$$
\left(\frac{T}{y}\right)_{i, t}=\beta_{0}+\beta_{1} A y_{i, t}+\beta_{2} s e r_{-} g d p_{i, t}+\beta_{3} i n d \_g d p+\varepsilon_{i, t}
$$


Therefore, equation (4) becomes the fundamental equation for this study, and forms the underlying framework on which subsequent estimations, analysis and discussions on which this study is based.

\section{Model Specification and Estimation Techniques}

This section contains models and estimation techniques examining the taxable capacity (taking into account sectoral compositions), the forecast error variance decomposition and impulse response functions or forecast performance of sectoral compositions in explaining taxes and the dynamic relationship between the various sectors of the ECOWAS countries and tax ratio.

\subsection{Sectoral Composition and Taxable Capacity}

To examine the taxable capacity of the ECOWAS countries in light of the sectoral compositions of the different economies, this study adopted the Stochastic Tax Frontier Analysis (STFA) based on the Stochastic Frontier Analysis (SFA) of Aigner, Lovell and Schmidst (1977) and Meeusen and Van de Broeck (1977) because the SFA enables us to define the maximum amount of tax revenue that ECOWAS countries could mobilize on the average from the period of 2000 to 2015 given her sectoral compositions. Hence, the basic Stochastic Tax Frontier Model of the ECOWAS countries in a panel data framework for the study is specified as:

$$
t_{\text {tax }} g d p_{i, t}=\alpha_{0}+\sum_{i=1}^{k} \alpha_{i} X_{i, t}+v_{i, t}-\mu_{i, t}
$$

Where, $\operatorname{tax} \_g d p_{i, t}$ represents total taxes, direct taxes and indirect taxes to gross domestic product ratio for country $i$ at time $t$, that is the actual maximum tax revenue mobilized taking into account the sectoral composition of the ECOWAS Countries.

$X_{i, t}$ represents the sectoral composition (agriculture, industry and services) affecting ECOWAS countries' taxable capacity. The taxable capacity of the ECOWAS countries are predicted based on Jondrow, Lovell, Materov and Schmidt's (1982) formula given by the observable values of $v_{i t}-\mu_{i t}$. However, the stochastic frontier models were estimated based on Battese and Coelli's (1995) framework. From the model specified, $\alpha_{i}$ denotes the vector of unknown parameters. Also, we assumed that the idiosyncratic error component, $v_{i}$, is independently $N\left(0, \sigma_{v}\right)$ distributed over the observations, while, the inefficiency term $\mu_{i}$ is assumed to be independently half - normally $N^{+}\left(0, \sigma_{u}{ }^{2}\right)$ distributed. The $\mu_{i}$ may also be assumed to be exponentially distributed with variance, $\sigma_{u}{ }^{2}$.

\subsection{Forecast Performance and Impulse Responses of Sectoral Composition of Taxes}

This section involves tracing the forecast performance and impulse response of taxes to the sectoral compositions of ECOWAS countries. This involves the use of the forecast error variance decomposition and impulse response function variants of the vector autoregressive model of the form:

$$
Y_{t}=\delta_{i t}+\sum_{i=1}^{k} \beta_{i j} Y_{t-j}+\varepsilon_{i t}
$$


Where $Y_{\mathrm{t}}=$ vector of variables [total taxes, direct taxes, indirect taxes, agriculture, industry and services], $\mathrm{Y}_{\mathrm{t}-1}=$ vector of lagged variables, $\delta_{i t}=$ vector of intercept terms, $\beta_{i j}=$ matrix of coefficients, $\varepsilon_{i t}=$ stochastic error terms. The model can provide a background for tracing the pattern of responses of taxes to the various sectors (agriculture, industry and service) of the ECOWAS countries.

\subsection{Dynamic Relationship between Sectoral Composition and Tax Performance}

In other to ensure smooth operationalization of the dynamic relationship between sectoral compositions and tax revenue there is need for a simultaneous equations framework because sectors (agriculture, industry and services) value added to national output and taxes may be endogenous in a long run relationship. Hence, the dynamic relationships can be ascertained by employing a methodology that would ensure simultaneity bias is eliminated. We therefore adopt the GMM estimation method for the analysis of the relationships. The GMM model is specified in the form of:

$y_{i, t}=\alpha_{0}+\alpha_{1} y_{i, t-1}+\alpha_{2} X_{i, t}+\varepsilon_{i t}$

Where: $y_{i, t}$ represents total taxes, direct taxes and indirect taxes as dependent variables in three variants of models, while $X_{i t}$ is vector comprising of agriculture value added, industry value added and service value added., while $i^{\prime} s$ and $t^{\prime} s$ represent individual country and time frame, respectively, and $\varepsilon_{i, t}$ denotes error term. The instrumental variables the Researcher used in this study were the lagged values of all the independent variables.

\section{Empirical Analysis}

\subsection{Sectoral Composition and Taxable Capacity}

This study estimated three baseline stochastic frontier models for ECOWAS countries taking into account the aggregate taxes and disaggregated tax components as dependent variables and the sectoral compositions as explanatory variables(see Table 1), this model is the fulcrum on which tax potential and tax effort estimates of the ECOWAS countries are based (see Table 2 in Annex 1).

The Wald tests for the models are significant at 1 percent level, implying that the tax and sectoral variables employed in the model are jointly significant, and the likelihood estimate is negative as expected by theory. The inefficiency parameters (sigma_u and eta) for the models are quite large and statistically significant at 1 percent, implying the rejection of the null hypotheses (sigma_u $u$ ) of no technical inefficiencies in the relationships between tax variables and sectoral composition. This is consistent with the studies of Cyan et al(2013) and Langford and Ohlenburg (2015) that reject the likelihood of no technical inefficiencies in stochastic frontier models. Also, this may have accounted for the relatively low tax-to-GDP ratio in ECOWAS countries.

Empirical evidence from the stochastic frontier models show that agriculture value added has significant and negative impact on direct and indirect taxes at $5 \%$ and $10 \%$ significance levels, and reveals negative and not significant effect in terms of total taxes in ECOWAS countries. Thus, this finding is indicative of the largely subsistence nature of the agricultural sector, and reflects the low taxable surplus from the sector. The industrial sector reveals positive and significant relationships with total taxes and direct taxes but shows a positive and non-significant relationship with indirect taxes. Also, the service sector shows positive and significant relationship with total taxes and direct taxes except for that of indirect taxes that reveals positive but non-significant relationship. Generally, the results show that the 
industrial and service sectors contribute more significantly to tax revenue than the agricultural sector in ECOWAS. However, more attention should be given to the formalization of tax revenue collections from the agricultural sector and base-broadening in other to pursue substantial indirect tax responsiveness to the revenue performance of ECOWAS countries.

Table 1: Sectoral Composition and Taxable Capacity: Stochastic Tax Frontier Analysis

\begin{tabular}{|c|c|c|c|c|c|c|c|c|}
\hline \multicolumn{9}{|c|}{ Battese Coelli - Half Normal Stochastic Tax Frontier Models } \\
\hline & \multicolumn{4}{|c|}{$\begin{array}{c}\text { Total } \\
\text { Taxes }\end{array}$} & \multicolumn{2}{|c|}{$\begin{array}{l}\text { Direct } \\
\text { Taxes }\end{array}$} & \multicolumn{2}{|c|}{$\begin{array}{c}\text { Indirect } \\
\text { Taxes }\end{array}$} \\
\hline Variables & Coef. & $\begin{array}{l}\text { St. } \\
\text { Error }\end{array}$ & Coef. & $\begin{array}{l}\text { St. } \\
\text { Error }\end{array}$ & Coef. & $\begin{array}{l}\text { St. } \\
\text { Error }\end{array}$ & Coef. & $\begin{array}{l}\text { St. } \\
\text { Error }\end{array}$ \\
\hline Total Tax+ & - & - & - & - & - & - & - & - \\
\hline $\begin{array}{l}\text { Direct } \\
\text { Tax++ }\end{array}$ & 0.16 & 0.14 & - & - & - & - & - & - \\
\hline $\begin{array}{l}\text { Indirect } \\
\text { Tax+++ }\end{array}$ & $0.39^{* * *}$ & 0.06 & - & - & - & - & - & - \\
\hline Agriculture & -0.01 & 0.02 & -0.02 & 0.02 & $-0.03^{* *}$ & 0.12 & $-0.98^{*}$ & 0.05 \\
\hline Industry & $0.11^{* * *}$ & 0.03 & $1.19^{* * *}$ & 0.03 & $0.15^{* * *}$ & 0.17 & 0.04 & 0.33 \\
\hline Service & $0.19^{* \star *}$ & 0.02 & $0.29^{\star * *}$ & 0.17 & $0.09^{* * *}$ & 0.97 & 0.04 & 0.06 \\
\hline Constant & -1.37 & 2.19 & -1.57 & 1.80 & -3.01 & 0.97 & $14.11^{* * *}$ & 4.05 \\
\hline \multicolumn{9}{|c|}{ Inefficiency } \\
\hline Lamda & 0.13 & 1.57 & 2.83 & 2.69 & 2.38 & 0.28 & & \\
\hline Eta & & & & & & & $-0.32^{\star \star *}$ & \\
\hline sigma(u) & 0.03 & 1.55 & 4.01 & 0.38 & 1.99 & 0.19 & 30.46 & 32.75 \\
\hline sigma_u=0 & 0.00 & & $17.18^{* * *}$ & & $11.19^{* * *}$ & & & \\
\hline \multicolumn{9}{|c|}{ Summary Statistics } \\
\hline $\begin{array}{l}\text { Wald } \\
\text { chi(2) }\end{array}$ & $440.77^{* \star *}$ & & $355.91^{* * *}$ & & $161.35^{* * *}$ & & $9.49^{*}$ & \\
\hline $\begin{array}{l}\text { log } \\
\text { likelihood }\end{array}$ & -477.14 & & -501.42 & & -369.73 & & -479.92 & \\
\hline
\end{tabular}

Source: Author's Computation,,++++++ dependent variables. ${ }^{* * *} /{ }^{* *}=10,5$ and 1 significant levels.

\subsection{Tax Potential and Tax Effort of ECOWAS Countries: Country-Specific}

This study conducted the inter-country comparisons(SeeTable 2 in Annex 1) of the average tax potential and tax effort estimates of thirteen ECOWAS countries, and a country with tax effort index in excess of unity is considered to be making appreciable effort in the collection of taxes and those below unity are considered to be making unappreciable tax collection efforts. We discuss the country-specific taxable capacities in this study:

Benin

The average actual tax ratio is about $16.20 \%$, and the country recorded a relatively low tax potential of about $15.85 \%$ with an appreciable effort index of 1.02, and this indicated that the country has made appreciable efforts in bridging the tax gaps by stimulating the tax collection efforts. However, there are relatively high potential for the mobilization of direct-and indirect tax efforts in the country.

Cape Verde 
The country has made tremendous effort in tax revenue collections taking into account the sectoral compositions of the economy. There is a substantial tax collection effort in terms of indirect taxes as compared to direct tax effort. However, the country is expected to make appreciable efforts towards direct tax revenue collection.

Burkina Faso

The country experienced a relatively moderate level of direct- $(0.67)$ and indirect $(0.55)$ tax efforts indices. Hence, there is substantial amount of taxable capacity with regards to the tax composition of the country.

Cote d' Ivoire

There is relatively large unexploited tax potential in the country. Hence, the tax effort indices range from 0.81 to 0.97 , though, there is an appreciable level of tax effort, however, considerable attention should be given to tax revenue mobilization.

Ghana

There is moderately high taxable capacity in the country. For instance, the tax potential is as high as 16.18 percent as compared to 13.14 percent of actual tax ratio. However, there is considerable high indirect taxable capacity in the country from the period of 2000 to 2015 .

Guinea

It is noticeable that the country has appreciable direct tax effort (about 0.85 ) as compared to indirect tax effort index of 0.65 . Hence, appreciable effort has not been made to exploring the opportunities inherent in the unexploited indirect tax potentials in the country.

Guinea Bissau

The country has a high level of direct and indirect tax potentials of about $3.86 \%$ and $10.76 \%$ as compared to the actual direct and indirect tax ratios of $0.62 \%$ and $2.10 \%$ respectively. Hence, the country has not made appreciable effort in reaping the taxable capacities provided by the various sectors of the country's economy.

Mali

The country has marginal difference between the actual tax ratio and tax frontier, for instance, the direct tax ratio is $3.65 \%$ as against tax frontier of $4.86 \%$, and indirect tax ratio of $10.54 \%$ as against tax frontier of $11.19 \%$. This estimate show that the country is making appreciable effort towards mobilizing direct and indirect taxes, but there is need for more effort in enhancing the revenue-earning capacity of the country's tax system.

Niger

There is considerably high level of tax potentials in the country. For instance, direct tax ratio is $2.48 \%$ as compared to tax frontier of $4.48 \%$, and indirect tax ratio of $8.36 \%$ compared to $10.94 \%$ tax frontier. Hence, the country requires more efforts to collecting more tax revenue.

Nigeria

There are huge unexploited tax potentials in the country taking into account the sectoral compositions of the country. For instance, the country's average direct tax ratio is $2.88 \%$ as against $5.78 \%$ tax frontier indicating a negative tax gap; and indirect tax ratio is $2.54 \%$ compared to tax frontier of $11.59 \%$, indicating a negative indirect tax gap, and this reveal that the country have a much higher indirect tax potential compared to that of direct tax potential. Hence, there is unappreciable effort made by the fiscal authorities of the country towards tax collections.

Senegal

There is huge unexploited direct and indirect tax potentials and an unappreciable direct and indirect tax efforts. For instance, actual direct tax ratio is $4.01 \%$ as against tax frontier of $6.18 \%$, and indirect tax ratio of $10.78 \%$ compared to indirect tax frontier of $13.86 \%$.

Sierra Leone

The country has witnessed a reasonably high level of tax efforts ranging from about 0.63 to 0.99 . However, the country has some unexploited tax potential that needed to be mobilized. Togo 
The country has a reasonably high taxable capacity considering the sectoral compositions of the country. For instance, the direct tax ratio is $2.01 \%$ as against the tax potential of $4.36 \%$, and indirect tax ratio of $4.96 \%$ as against indirect tax frontier of $12.07 \%$. These estimates show that the country has not made tremendous progress in the mobilization of tax revenue from 2000 to 2015 .

\subsection{Forecast Performance of Sectoral Composition in Explaining Taxes}

The effects of sectoral composition on tax revenue are presented using empirical outcomes from estimated forecast error variance decomposition (FEVD) of the vector autoregressive (VAR) equation. The FEVD is used to show how much the agriculture, service and industrial sectors explain the aggregative and disaggregated components of tax system of ECOWAS countries. The FEVD estimates are presented in Table 6.

In terms of total taxes, the agricultural sector explains an increasing proportion of total tax revenue overtime, with the proportion reaching a considerable high level of $5.22 \%$ in the tenth period. This shows that the agricultural sector is expected to have stimulated the taxable capacity of the ECOWAS countries in the period under study. For the other sectors, the FEVD results show that the service sector substantially contributes more significantly to total tax revenue at the tenth period to the tune of $5.71 \%$ as compared to that of the agricultural sector. The results show that the industrial sector perform worse in explaining the variances in total tax revenue; it only explains a maximum of $3.32 \%$ points in the tenth period.

In terms of direct taxes, the industrial sector performs quite well in the FEVD, the sector explained a substantial proportion of direct taxes, indicating that the industrial sector explains direct taxes to the tune of $4.31 \%$ in the tenth period as against the $2.42 \%$ and $0.14 \%$ of the agriculture and the service sectors respectively.

In terms of indirect taxes, the service sector took the lead to as high as $1.06 \%$ in the tenth period in its explanation of the variance in indirect taxes. However, the agricultural-and industrial sectors apparently show low performance to explaining the variance in indirect taxes in ECOWAS countries.

Table 3: Forecast Performance of Sectoral Composition in Explaining Taxes in ECOWAS Countries

\begin{tabular}{|c|c|c|c|c|c|c|c|c|c|}
\hline & \multicolumn{3}{|c|}{ Total Taxes } & \multicolumn{3}{c|}{ Direct Taxes } & \multicolumn{3}{c|}{ Indirect Taxes } \\
\hline Horizon & $\begin{array}{c}\text { Agric } \\
\text { ulture }\end{array}$ & Service & Industry & $\begin{array}{c}\text { Agric } \\
\text { ulture }\end{array}$ & Service & Industry & $\begin{array}{c}\text { Agric } \\
\text { ulture }\end{array}$ & Service & Industry \\
\hline 1 & 0.00 & 0.00 & 0.00 & 0.00 & 0.00 & 0.00 & 0.00 & 0.00 & 0.00 \\
\hline 2 & 1.00 & 0.02 & 0.12 & 0.19 & 0.10 & 0.01 & 0.00 & 0.00 & 0.13 \\
\hline 3 & 1.50 & 0.18 & 0.56 & 0.42 & 0.12 & 0.25 & 0.00 & 0.01 & 0.14 \\
\hline 4 & 2.08 & 0.58 & 0.94 & 0.67 & 0.11 & 0.67 & 0.02 & 0.04 & 0.13 \\
\hline 5 & 2.62 & 1.21 & 1.34 & 0.95 & 0.10 & 1.22 & 0.06 & 0.10 & 0.13 \\
\hline 6 & 3.16 & 2.00 & 1.74 & 1.24 & 0.10 & 1.84 & 0.12 & 0.20 & 0.14 \\
\hline 7 & 3.69 & 2.88 & 2.14 & 1.54 & 0.10 & 2.48 & 0.19 & 0.35 & 0.19 \\
\hline 8 & 4.21 & 3.82 & 2.54 & 1.84 & 0.11 & 3.12 & 0.29 & 0.55 & 0.26 \\
\hline 9 & 4.72 & 4.77 & 2.93 & 2.13 & 0.12 & 3.74 & 0.39 & 0.79 & 0.35 \\
\hline 10 & 5.22 & 5.71 & 3.32 & 2.42 & 0.14 & 4.31 & 0.51 & 1.06 & 0.46 \\
\hline
\end{tabular}

Source: Author's Computation 


\subsection{Responses of Sectoral Composition in Explaining Taxes}

The interactive responses between the sectoral composition and taxes of ECOWAS countries are explained by the Impulse Response Functions (IRFs) estimates of the VAR model (See Table 4). Apparently, the agricultural sector is negatively related to total taxes, direct taxes and indirect taxes, indicating the adverse contributions or interactions of the agricultural sector to the taxable surplus of ECOWAS countries. For the other sectors, the service sector (except for the second period) and industrial sector contribute positively to explaining total taxes in ECOWAS countries. In terms of direct-and indirect taxes, a relatively high number of periods show that the service sector and industrial sector are positively related to explaining the direct and indirect tax revenues. Generally, the service and industrial sectors express favourable responses to the tax revenue performance except the agricultural sector that shows otherwise.

Table 4: Responses of Sectoral Composition in Explaining Taxes

\begin{tabular}{|c|c|c|c|c|c|c|c|c|c|}
\hline & \multicolumn{3}{|c|}{ Total Taxes } & \multicolumn{3}{c|}{ Direct Taxes } & \multicolumn{3}{c|}{ Indirect Taxes } \\
\hline Horizon & $\begin{array}{c}\text { Agric } \\
\text { ulture }\end{array}$ & Service & Industry & $\begin{array}{c}\text { Agric } \\
\text { Ulture }\end{array}$ & Service & Industry & $\begin{array}{c}\text { Agric } \\
\text { ulture }\end{array}$ & Service & Industry \\
\hline 1 & 0.00 & 0.00 & 0.00 & 0.00 & 0.00 & 0.00 & 0.00 & 0.00 & 0.00 \\
\hline 2 & -0.17 & -0.02 & 0.06 & -0.06 & -0.04 & 0.01 & -0.01 & 0.01 & -0.10 \\
\hline 3 & -0.16 & 0.08 & 0.13 & -0.08 & -0.03 & 0.07 & -0.02 & 0.03 & -0.06 \\
\hline 4 & -0.19 & 0.14 & 0.14 & -0.09 & -0.01 & 0.10 & -0.05 & 0.05 & -0.02 \\
\hline 5 & -0.21 & 0.19 & 0.16 & -0.09 & 0.00 & 0.13 & -0.07 & 0.08 & 0.02 \\
\hline 6 & -0.22 & 0.23 & 0.18 & -0.10 & 0.01 & 0.14 & -0.08 & 0.11 & 0.05 \\
\hline 7 & -0.23 & 0.26 & 0.19 & -0.10 & 0.01 & 0.14 & -0.10 & 0.14 & 0.08 \\
\hline 8 & -0.24 & 0.29 & 0.20 & -0.10 & 0.02 & 0.15 & -0.11 & 0.16 & 0.10 \\
\hline 9 & -0.25 & 0.31 & 0.21 & -0.10 & 0.02 & 0.14 & -0.12 & 0.18 & 0.11 \\
\hline 10 & -0.26 & 0.32 & 0.22 & -0.10 & 0.02 & 0.14 & -0.13 & 0.20 & 0.13 \\
\hline
\end{tabular}

Source: Author's Computation

\subsection{Dynamic Relationship between Taxation and Sectoral Composition}

Table 5 shows the results from the Generalized Methods of Moment model, and the variables employed are in their first difference based on the Arellano-Bond's estimation procedure. The diagnostic statistics are quite impressive. The coefficient of determinations show that the sectoral composition of the economies explains about $89 \%, 75 \%$ and $70 \%$ of total taxes, direct taxes and indirect taxes in ECOWAS countries. The Hansen's J over-identifying restriction test of our respective models indicate the acceptance of null hypothesis of the validity of the instruments. Also, the study reports the absence of first order autocorrelation (in terms of direct and indirect taxes models) and second order autocorrelation (in terms of total taxes and indirect taxes).

The effect of agriculture as share of GDP is negative and statistically non-significant suggesting the large subsistence nature of the sector, and a low taxable surplus of the agricultural sector in the ECOWAS countries.

The effect of the service sector is positive and statistically significant at $1 \%$ and $10 \%$ significance levels in terms of the total taxes, direct taxes and indirect taxes. This finding suggests that a favourable improvement in the activities of the service sector will stimulate the tax revenue performance of the ECOWAS countries.

The industrial sector has a statistically significant (except in the case of indirect taxes) and positive impact on the ECOWAS countries' tax revenue. The improvement in the industrial sector will enhance the revenue-earning capacity of the tax revenue of ECOWAS countries. 
Table 5: Dynamic Relationship between Taxation and Sectoral Composition

\begin{tabular}{|l|c|c|c|c|c|c|}
\hline & \multicolumn{2}{|c|}{ Total Taxes } & \multicolumn{2}{c|}{ Direct Taxes } & \multicolumn{2}{c|}{ Indirect Taxes } \\
\hline Variables & coef. & t-stat. & coef. & t-stat. & coef. & t-stat. \\
\hline Tax Ratio (-1) & $0.88^{* * *}$ & 23.65 & & & & \\
\hline Direct Taxes (-1) & & & $0.81^{* * *}$ & 18.14 & & \\
\hline Indirect Taxes (-1) & & & & & $0.78^{* * *}$ & 16.77 \\
\hline Agriculture & -0.01 & -0.55 & -0.02 & -0.45 & -0.01 & -0.55 \\
\hline Service & $0.03^{* * *}$ & 2.62 & $0.01^{*}$ & 1.77 & $0.04^{* * *}$ & 2.72 \\
\hline Industry & $0.02^{* *}$ & 1.98 & $0.02^{* *}$ & 2.27 & 0.01 & 0.92 \\
\hline R- Square & 0.89 & & 0.75 & & 0.70 & \\
\hline Adjusted R-Square & 0.89 & & 0.75 & & 0.70 & \\
\hline J-Statistics & 0.90 & & 1.33 & & 2.81 & \\
\hline AR (1) & - & & -60.83 & & -264.07 & \\
\hline AR(2) & 7.25 & & $-30.42^{*}$ & & -323.61 & \\
\hline
\end{tabular}

Source: Author's Computation. ${ }^{* * * / * * / *}=1,5$ and 10 significance levels

\section{Policy Implications, Recommendations and Conclusion}

The implications that emanates from this study includes; general inefficiency in tax administration resulting in low tax-to-GDP ratio in ECOWAS countries, huge proportion of agricultural activities is still being carried out in subsistence nature in ECOWAS countries reflecting in the low taxable surplus and poor effect of agricultural share of GDP. Other policy implications are: the industrial and service sectors contribute more significantly to tax revenue than the agricultural sector in ECOWAS countries, ECOWAS countries have a reasonably high taxable capacity considering these sectoral compositions yet to be maximally exploited, the service and industrial sectors expresses favourable responses to the tax revenue performance compared to the agricultural sector.

In the light of the above, the following recommendations are suggested;

1. Efforts should be made by relevant authorities on ECOWAS countries to formalize and strengthens tax revenue collections in agricultural sector in other for the sector to be more responsiveness to tax revenue performance.

2. Efforts should also be made to enhance activities in the service and industrial sectors to stimulate more tax revenue performance in ECOWAS countries.

3. Agencies saddled with the responsibility of tax administration in ECOWAS countries should be strengthen in other for them to perform optimally. This has the potency of improving tax revenue performance generally.

In conclusion, this study investigated the taxable capacity, tax efforts and tax structure of ECOWAS countries taking into account sectoral composition (Agriculture, service and industrial) of thirteen ECOWAS countries for the period 2000 to 2015 . This was informed by the need to ease and strengthen the level of international comparability of countries' tax efforts and aid better understanding of tax revenue performance along three major sectors of the economy of ECOWAS countries. Based on the theoretical framework, models were built along sectoral composition and Taxable capacity, forecast performance and impulse responses of sectoral composition in Explaining taxes and dynamic relationship between sectoral composition and tax performance. 
It was found that ECOWAS countries have a reasonably high taxable capacity considering these sectoral compositions though yet to be maximally exploited. This implies a rejection of the hypothesis that ECOWAS countries have low taxable capacity. It was also revealed that the service and industrial sectors express favourable responses to the tax revenue performance compared to the agricultural sector. This also implies a rejection of the hypothesis that there is a low tax effort in ECOWAS countries. However, the study revealed that the industrial and service sectors contribute more significantly to tax revenue than the agricultural sector in ECOWAS countries.

\section{Acknowledgements:}

We acknowledged the supports of different authors in the areas of public finance whose literature were reviewed. Also, we appreciate the International Centre for Tax Development and the World Bank for the various academic resources used for this study.

\section{References}

Aigner, D., Lovell, C.A.K., and Schmidt, P. 1977. Formulation and estimation of stochastic frontier production function models. Journal of Econometrics, 6, pp. 21-37.

Arnold, J. 2008. Do tax structures affect aggregate economic growth; empirical evidence from a panel of OECD countries, OECD Economics Department Working Papers, 5(2), pp. 44-49. http://Dx.Doi.Org/10.1787/236001777843. [Accessed April 2019]

Battese, G.E. and Coelli, T.J. 1995. A model for technical inefficiency effects in a stochasticfrontier production for panel data. Empirical Economics, 20, pp. 325-332.

Cyan, M., Martinez-Vazquez, J., and Vulovic, V. 2013 Measuring tax effort: Does the estimation approach matter and should effort be linked to expenditure goals? Working Paper 08. Georgia, United State of America: International Center for Public Policy.

Hinrichs, H.H. 1966. A general theory of tax structure change during economic development. Cambridge, Massachusetts: Harvard Law School International Tax Programme.

Im, K.S., Pesaran, M.H, M.H., and Shin, Y. 2003. Testing for unit roots in heterogeneous panel. Journal of Econometrics, 115, pp. 53 - 74.

Jondrow, J., Lovell, C.A.K., Materov, I.S., and Schmidt, P. 1982. On the estimation of technical Inefficiency in the stochastic frontier production function model. Journal of Econometrics, 19, pp. 233-238.

Langford, B. and Ohlenburg, T. 2015. Tax Revenue potential and effort: an empirical investigation (Working Paper). Houghton, London: International Growth Centre

Levin, A., Lin, C., and Chu, J. 2002. Unit root tests in panel data: Asymptotic and finite -sample Properties. Journal of Econometrics. 108, pp.1-24.

Meeusen, W., and Van de Broeck, J. 1977. Efficiency estimation from Cobb-Douglas production functions with composed error. International Economic Review, 18, pp.435-444. Musgrave, R.A. 1969. Fiscal Systems. New Haven, CT: Yale University Press. Musgrave, R. and Musgrave, P. 1982. Public finance in theory and practice. Tokyo: McGraw-Hill International Book Company.

\section{Bio-notes}

Nosakhare Liberty Arodoye (Dr.) is a lecturer in the Department of Economics, University of Benin, Nigeria. He received his doctorate in the same department. His area of interest is public finance.

John Norense Izevbigie (Mr.) is also a lecturer in the Department of Economics, University of Benin, Nigeria. He is at present a doctoral student in the same department with international trade and finance as areas of interest. 


\section{Annex 1}

Table 2: Sectoral Composition, Tax Structure and Taxable Capacity in ECOWAS Countries, Averages, 2000-15

\begin{tabular}{|c|c|c|c|c|c|c|c|c|c|c|c|c|c|}
\hline & 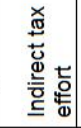 & $\begin{array}{c}\hat{\sigma} \\
0 \\
0\end{array}$ & ¿ָ- & & 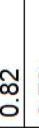 & ‥ & ؛ొ. & $\stackrel{0}{\circ}$ & \begin{tabular}{l|l} 
S \\
S
\end{tabular} & $\begin{array}{r}\hat{0} \\
0\end{array}$ & 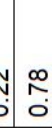 & $\begin{array}{l}0 \\
0 \\
0\end{array}$ & $\begin{array}{l}\bar{\sigma} \\
0\end{array}$ \\
\hline 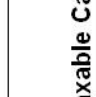 & 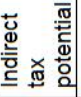 & 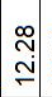 & & & & $\begin{array}{l}\stackrel{8}{\circ} \\
\leftarrow \\
\end{array}$ & & & $\stackrel{9}{=}$ & & 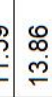 & 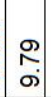 & $\stackrel{\hat{O}}{\mathrm{i}}$ \\
\hline 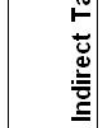 & 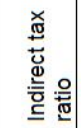 & $\stackrel{\stackrel{\leftrightarrow}{\circ}}{\stackrel{5}{\leftarrow}}$ & $\begin{array}{c}\stackrel{\infty}{\infty} \\
\stackrel{N}{\sim}\end{array}$ & & 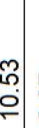 & 商 & סֶ. & 원 & 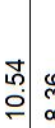 & 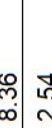 & 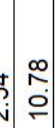 & \begin{tabular}{l}
$f$ \\
\hdashline
\end{tabular} & 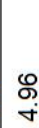 \\
\hline : & 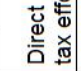 & 足 & & & ז. & ๑ొ & : & $\frac{0}{0}$ & 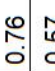 & ț. & \begin{tabular}{l}
0 \\
\hdashline \\
\end{tabular} & $\begin{array}{c}0 \\
0 \\
0\end{array}$ & ปे \\
\hline 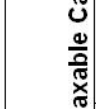 & 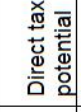 & $\begin{array}{c}0 \\
2 \\
\omega \\
\end{array}$ & & & & $\begin{array}{c}7 \\
i\end{array}$ & ?ִ & $\begin{array}{l}0 \\
0 \\
m \\
\end{array}$ & 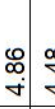 & 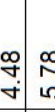 & 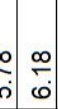 & $\underset{m}{\bar{m}}$ & $\begin{array}{l}\mathscr{O} \\
\stackrel{\sim}{+}\end{array}$ \\
\hline . & 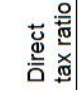 & $\stackrel{\stackrel{\sim}{\sim}}{\underset{\sim}{\sim}}$ & \begin{tabular}{l|l}
$\infty$ & 1 \\
\hdashline & 1
\end{tabular} & $-\sqrt{v}$ & 产 & 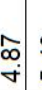 & ชุ & 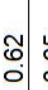 & 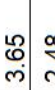 & 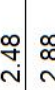 & \begin{tabular}{l}
$:$ \\
\hdashline
\end{tabular} & $\underset{N}{N}$ & $\underset{\sim}{\bar{N}}$ \\
\hline 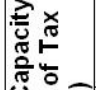 & & $\begin{array}{c}\text { ô } \\
\text { ○े }\end{array}$ & 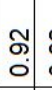 & & & 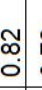 & $\begin{array}{c}\infty \\
\stackrel{2}{0} \\
\vdots\end{array}$ & $\begin{array}{l}8 \\
0 \\
0\end{array}$ & \begin{tabular}{l|l}
8 & 1 \\
0 & 1 \\
0
\end{tabular} & 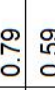 & 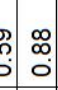 & $\begin{array}{l}n \\
\stackrel{2}{0} \\
0\end{array}$ & 哭 \\
\hline 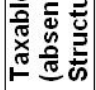 & 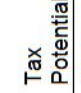 & $\begin{array}{l}₫ \\
\stackrel{0}{\sim}\end{array}$ & & & 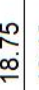 & $\stackrel{\infty}{\stackrel{\infty}{\circ}}$ & & 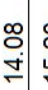 & 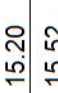 & 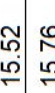 & & 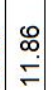 & 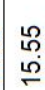 \\
\hline 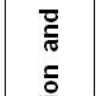 & & 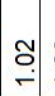 & $\stackrel{8}{\bullet}$ & : & 命. & 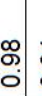 & ১. & 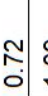 & 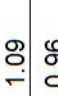 & ๑. ஃ & 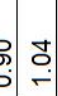 & 。․ & $\stackrel{\mathrm{m}}{-}$ \\
\hline 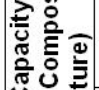 & & $\begin{array}{ll}\infty & \\
\infty & \\
\stackrel{\rho}{\circ} & \\
\end{array}$ & $\begin{array}{l}\text { ôt } \\
\text { î: }\end{array}$ & 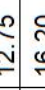 & $\begin{array}{c}\text { ํ. } \\
\text { : }\end{array}$ & . & 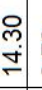 & 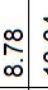 & 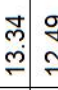 & 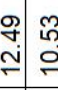 & 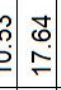 & $\begin{array}{c}\tilde{s} \\
\sigma \\
\sigma\end{array}$ & $\stackrel{\text { m}}{\leftarrow}$ \\
\hline 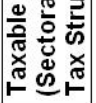 & 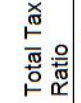 & \begin{tabular}{l}
0 \\
\multirow{2}{*}{} \\
0
\end{tabular} & 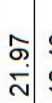 & $\underset{v}{*}$ & 童 & c. & 容 & $\stackrel{\hat{c}}{\hat{0}}$ & \begin{tabular}{l|l}
$\stackrel{5}{i n}$ \\
\multirow{0}{*}{}
\end{tabular} & 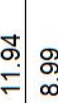 & 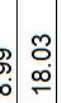 & $\mid \begin{array}{c}\mathbb{D} \\
\substack{\infty \\
\infty}\end{array}$ & $\begin{array}{l}\stackrel{8}{\bullet} \\
\dot{J}\end{array}$ \\
\hline & ن & 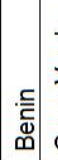 & 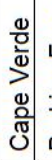 & 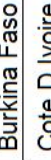 & . & $\begin{array}{l}\frac{\pi}{2} \\
\frac{\pi}{0} \\
\frac{\pi}{0}\end{array}$ & $\underset{\mathbb{\Xi}}{\mathbb{\Phi}}$ & $\begin{array}{c}m \\
\sigma \\
\sigma\end{array}$ & 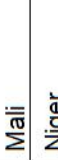 & $\begin{array}{lll}\frac{1}{2} \\
\frac{0}{2} \\
\frac{0}{2}\end{array}$ & 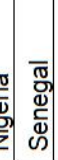 & 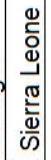 & 。 \\
\hline
\end{tabular}

Source: Authors' Computation 